\title{
Effect of lateral spacing on marketable yield and irrigation production efficiency on tomato crop
}

\author{
${ }^{*}$ Mukesh Rana ${ }^{1 *}$ and Monu ${ }^{2}$ \\ ${ }^{1}$ Department of Farm Machinery Power Engineering \\ ${ }^{2}$ Department of Irrigation and Drainage Engineering. \\ College of Technology, GBPUAT, Pantnagar (Uttarakhand). \\ Email: rana.gbpaut@gmail.com
}

\begin{abstract}
The experiment was conducted at G.B. Pant University of Agriculture and Technology, Pantnagar during the winter crop growing period in order to examine the effect of lateral spacing on marketable yield and irrigation production efficiency of tomato. The soil of the experimental field was fertile clay loam, (35.5\% sand, 35.8\% silt and $38.6 \%$ clay) with average bulk density of $1.31 \mathrm{~g} \mathrm{~cm}^{3}$. The moisture content at field capacity (-13 bar) and wilting point (-15 bar) was $1.95 \%$ and $9.1 \%$ on an oven dry sight loss basis respectively. The plant available soil moisture was $136.2 \mathrm{~mm} / \mathrm{m}$. The experiment consist two lateral spacing viz. $0.5 \mathrm{~m}$ for every row and $1.0 \mathrm{~m}$ for alternative rows. The lateral spacing of $0.5 \mathrm{~m}$ gave higher marketable yield and irrigation production efficiency as compared with $1.0 \mathrm{~m}$ lateral spacing.
\end{abstract}

Keywords: Lateral spacing, marketable yield, irrigation, production efficiency, tomato crop.

Paper cited: Rana, M. and Monu (2015). Effect of lateral spacing on marketable yield and irrigation production efficiency on tomato crop. South Asian Journal of Food Technology and Environment, 1(3\&4): 266-273.

Received: 30/09/2015 Revised: 09/09/2015 Accepted 1/10/2015

\section{Introduction}

India is basically a semi-arid country with limited surface and sub-surface water source. Due to increasing population and rapid industrialization the demand of water is increasing considerably. For every growing population, water for Irrigation is becoming both search and expensive (Ayars et al., 1995). Due to fast depletion of surface and subsurface water resource, caused by over exploitation and erratic rain fall, it is therefore essential to formulate and adopt and efficient and reliable water application method and other techniques of crop production like lateral spacing etc. therefore efficient and economically variable irrigation water and other Input management strategies in order to irrigate more land area with existing water resources for crop production is required (Doss et al., 1980). The use of irrigation methods or system that requires low labor and energy input has become more popular in recent year these conditions and readily satisfied by means of drip (micro) irrigation system the means to deliver water to the soil in small and frequent quantities at a relatively low cost compared to other pressurized system therefore, water more efficient than in other irrigation methods. (Breslur,1978).

In addition, economic and environment reasons increasing irrigation costs and decreasing sources of irrigation have encouraged fanner to use drip irrigation. Drip irrigation can apply water more precisely and uniformly, potentially reducing subsurface drainage controlling soil salinity and measuring yield. Drip irrigation is characterized by localized, frequent application of water and such regime restricts the fluctuations in soil water potential within a narrow range high maintains a favorable soil water regimes, leading to high yields (Breslur, 1977). In some cases the advantage of drip irrigation over other methods was related to a variety of factors such as, water logging and management deficiencies (Sammis, 1980). 
Low soil permeability (Grimes et al., 1976) and the different criteria followed to determine the amounts of applied water by the various irrigation methods.

Drip or trickle irrigation may be used to overcome these concerns (Bucks et al., 1982). Irrigation volumes erosion and addition to ground water can be reduce with the more controlled water application that is characteristics of drip irrigation scheduling is defined as deeding when to irrigative and how much water to apply several types of irrigations scheduling as belonging to one of two broad soil water balance computations and soil crop monitoring technique (Farah et al., 1997). The management of water resource in irrigation is a fundamental aspect for their sustainability (Hanson et al., 1970). Optimal water management is essential in irrigated and region to sustain productivity conserve water resource and protect ground water quality (Imtiyaz et al., 2000; Sivanappam et al., 1987 and Wanjura, 1990).

Tomato is one of the important vegetable crop grown in India and is regarded as a cash crop. Researchers have shown that higher tomato yields are obtained by drip irrigation (Parihar, 1974). Tomato required warm weather and plenty of sunshine with proper irrigation for its best development, tomato of a variety or soil ranging from sandy loam to heavy clay, soil with a $\mathrm{pH}$ of 6-7 is idea. Jadhav et al., (1990) tested drip and furrow method for tomatoes. Tomatoes yield were $36 \mathrm{t} / \mathrm{ha}$ for drip irrigation systems and 32 $\mathrm{t} / \mathrm{ha}$ when furrow irrigation was used. The total production of tomato crop in India is approximately 5.3 million tonnes in Uttar Pradesh. Tomato Crop occupies 36,682 ha producing about 1,14,200 tonnes annually. Productivity of tomato in UP is 2120 tonnes/ha.

\section{Material and Methods}

The field experiment was conducted during the winter crop growing period in order to examine the effect of variable irrigation on economic return of tomato. The climate in this part of country has been classified as semi-arid with cold winter and hot summer. The soil of the experimental field was fertile clay loam, (35.5\% sand, $35.8 \%$ silt and $38.6 \%$ clay) with average bulk density of $1.31 \mathrm{~g} \mathrm{~cm}^{3}$. The climatic parameters during the crop growing periods are summarized in Table1. The moisture content at field capacity ( -13 bar) and wilting point (-15 bar) was $1.95 \%$ and $9.1 \%$ on an oven dry sight loss basis respectively. The plant available soil moisture was $\mathbf{1 3 6 . 2}$ $\mathrm{mm} / \mathrm{m}$.

Table 1: Climatic parameters during the crop growing period of 2011-2012.

\begin{tabular}{|c|c|c|c|c|c|c|}
\hline Months & $\begin{array}{c}\text { Mean wind } \\
\text { velocity } \\
\mathbf{( k m} / \mathbf{h r})\end{array}$ & $\begin{array}{c}\text { Mean } \\
\text { sunlight } \\
\mathbf{( h o u r s})\end{array}$ & $\begin{array}{c}\text { Mean } \\
\text { humidity } \\
\mathbf{( \% )}\end{array}$ & $\begin{array}{c}\text { Mean } \\
\text { Max } \\
\text { temp }\left({ }^{\mathbf{0}} \mathbf{C}\right)\end{array}$ & $\begin{array}{c}\text { Mean } \\
\text { min temp } \\
\mathbf{(} \mathbf{C})\end{array}$ & $\begin{array}{c}\text { Mean } \\
\text { evaporati } \\
\text { on (mm) }\end{array}$ \\
\hline Nov. & 7.1 & 1.97 & 71.18 & 26.4 & 9.1 & 2.29 \\
\hline Dec. & 4.01 & - & 73.75 & 21.1 & 8.5 & 1.55 \\
\hline Jan. & 4.70 & - & 71.14 & 18.3 & 8.4 & 1.75 \\
\hline Feb. & 8.37 & - & 57.16 & 21.8 & 7.56 & 3.22 \\
\hline Mar. & 8.74 & - & 44.94 & 26.2 & 9.3 & 5.18 \\
\hline
\end{tabular}


The experiment was laid out in a two factor complete randomized block design with three replications. It comprises of 10 treatments with five water levels and two lateral spacing. The area of each experimental plot was $9 \mathrm{~m}^{2}$. Tomatoes seed was shown on $24^{\text {th }}$ November 2010 in the nursery at a depth of $0.05 \mathrm{~m}$ with spacing of $10 \mathrm{~cm}$ between rows. The seed bed was irrigated regularly and converted with dry straw of $6 \mathrm{~cm}$ thickness and treated with gamaxene in order to facilitate good emergence. The seedlings were transplanted on $25^{\text {th }}$ Dec 2010 at a spacing of $0.5 \mathrm{~m} \times 0.5 \mathrm{~m}$. A butter zone spacing of $0.5 \mathrm{~m}$ was provided between the plots. Before plotting experimental field of tomato it was well irrigated, properly ploughed well pulverized and leveled to provide good filth. Prior to transplanting, the experimental field of tomato received $66 \mathrm{~kg} / \mathrm{ha} \mathrm{N}, 94.3 \mathrm{~kg} /$ ha $\mathrm{P}_{2} \mathrm{O}_{5}$ and $62 \mathrm{~kg} / \mathrm{ha} \mathrm{K}_{2} \mathrm{O}$.

The experiment consisted of two lateral spacing. The details of the treatments are as follows:

\section{Lateral Spacing}

- $\mathrm{LS}_{1}=0.5 \mathrm{~m}$ (laterals in every rows).

- $\mathrm{LS}_{2}=1.0 \mathrm{~m}$ (laterals in alternative rows).

\section{Irrigation Levels}

- $\mathrm{I}_{1}$ Irrigation at $25 \%$ of pan evaporation replenishment

- $\mathrm{I}_{2}$ Irrigation at $75 \%$ of pan evaporation replenishment

- $\mathrm{I}_{3}$ Irrigation at $125 \%$ of pan evaporation replenishment

- $\mathrm{I}_{4}$ Irrigation at $175 \%$ of pan evaporation replenishment

- $\mathrm{I}_{5}$ Irrigation at $225 \%$ of pan evaporation replenishment

The layout of the experiment is presented in Fig.1. The daily evaporation data from USWB class A open pan for a period of five year (2004-2009) were collected. Crop was irrigated when the sum of the daily mean (3 years) of pan evaporation reached approximately to a predetermined value of $16.3 \mathrm{~mm}$ (rooting depth in $\mathrm{m} x$ plant available soil moisture in $\mathrm{mm} / \mathrm{m} \times$ readily available soil moisture in fraction.

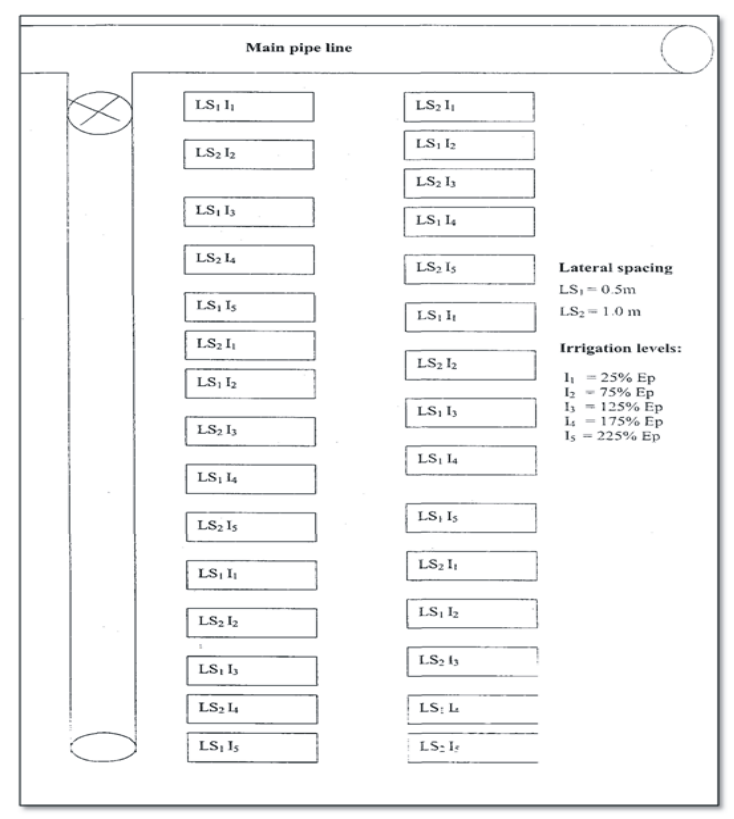

Fig. 1: Schematic Layout of Field

\section{Experiment.}

The irrigation water was pumped directly from borehole to the concrete tank. The irrigation water was lifted from the concrete tank with the help of electric motor to the drip irrigation system. Screen liter was installed on the main line to minimize dripper blockage. PVC pipes of $50 \mathrm{~mm}$ and low density polyethylene (LDPE) pipes of $12 \mathrm{~mm}$ diameter were used for sub main and lateral line respectively. The lateral line was laid to each crop rows as well as in alternative row. Plants of tomato were watered by $4 \mathrm{l} / \mathrm{h}$ non pressure compensated on line dippers. The space between drippers was $0.5 \mathrm{~m}$. The sub main line was connected to a water meter and 
a control valve in order to deliver the desired amount of after to the respective treatments.

In order to assess the economic viability of drip irrigation system under variable irrigation and lateral spacing, both fixed and operation costs were include. Total cost of production, gross return and net return under different irritation levels was estimated on the following assumption,

Salvage value of the deponents

$$
=0
$$

Useful life of tube well, pump, motor and pump house

$$
=25 \text { years }
$$

Useful life of drip irrigation systems

$$
=8 \text { years }
$$

Useful life of weeding and spraying

$$
\begin{aligned}
\text { equipment } & =7 \text { years } \\
\text { Interest rate } & =12.5 \% \\
\text { Repair \& maintenance } & =2.5 \% \\
\text { No. of Crops/year } & =2
\end{aligned}
$$

The fixed cost including water development (tube well, pump, motor, pump house and irrigation system etc.). Poly vinyl chloride (PVC) and low density polyethylene (LDPE) pipe for main and laterals, filters, fertilizer units pressure gauges, water meter, drippers, spraying and weeding equipment and other accessories were calculated by the approach.

$$
C R F=\frac{i(1+i)^{n}}{(1+i)^{n-1}}
$$

Where,

$$
\begin{aligned}
& \mathrm{CRF}=\text { Capital Recovery factor } \\
& \mathrm{i} \quad=\text { Interest rate, Faction } \\
& \mathrm{N} \quad=\text { Useful life of the } \\
& \begin{array}{l}
\text { components (year) } \\
\text { Annual fixed cost/ ha }=\mathrm{CFR} \times \text { fixed }
\end{array}
\end{aligned}
$$

$$
\begin{aligned}
& \text { Annual fixed cost } / \mathrm{ha} / \mathrm{season}= \\
& \frac{\text { Annual fixed cost } / \mathrm{ha}}{2}
\end{aligned}
$$

The operating cost including labor (system installation, fertilizer /chemical application and harvesting etc.), land preparation, seeds, fertilizer/chemical, water pumping were estimated. The gross return was calculated taking into consideration the marketable yield and current wholesale price of tomato. Subsequently the net return for tomato was calculated consider in total cost of producing and gross return.

Gross return $=$ marketable yield $(\mathrm{kg} / \mathrm{ha}) \times$ market price of tomato $(\mathrm{Rs} . / \mathrm{kg})$

Net return $(\mathrm{Rs} / \mathrm{ha})=$ Gross return (Rs/ha) - Total cost of production (Rs./ha) The benefit cost ratio $\mathrm{B} / \mathrm{C}$ was calculated as follows:-

$$
\mathrm{B} / \mathrm{C}=\frac{\text { Gross return }(\mathrm{Rs} / \mathrm{ha})}{\text { Totalcostof production }(\mathrm{Rs} / \mathrm{ha})}
$$

Total cost of production=fixed cost + operating cost.

\section{Results and discussion}

Yield and irrigation production efficiency

The effect of irrigation schedule and lateral spacing on marketable yield and irrigation production efficiency of tomato are shown in Table 2. The marketable yield to tomato under different irrigation level range from $28.19 \mathrm{t} / \mathrm{ha}$. The marketable yield of tomato increased significantly with an increase in irrigation level up $175 \%$ of pan evaporation replenishment. It produced highest marketable yield of $57.66 \mathrm{t} / \mathrm{ha}$. A further increase in irrigation level up to $225 \%$ of pan evaporation replenishment reduced the marketable yield as $53.61 \mathrm{t} / \mathrm{ha}$. This is due to the excessive vegetative growth and reduction in number of fruits or plants which resulted in loss of mean fruit weight induced by excessive soil moisture condition. Marketable yield of tomato for two lateral spacing are presented in Fig. 2. The seasonal water applied for different irritation levels ranged from $98 \mathrm{~mm}$ to 882 $\mathrm{mm}$ whereas the marketable yield for $\mathrm{LS}_{1}$ ( 0.5 ) and $\mathrm{LS}_{2}$ (1.0) m lateral spacing 49.23t/ha and $43.50 \mathrm{t} / \mathrm{ha}$ respectively. 
The irrigation production efficiency decreased significantly with an increase in irrigation levels from $25 \% \mathrm{Ep}$ to $225 \% \mathrm{Ep}$ (Table 2). This is because of the ratio of seasonal water application and marketable fruit yield was high as compare with other irrigation levels their marketable yield. The irrigation at $25 \%$ of pan evaporation replenishment resulted in significantly maximum irrigation production efficiency of $\left(28.81 \mathrm{~kg} / \mathrm{in}^{3}\right)$. The irrigation at $225 \%$ evaporation replenishment resulted at significantly minimum irrigation production efficiency $\left(6.07 \mathrm{~kg} / \mathrm{m}^{3}\right)$. Because it increased the seasonal water applied but at the same time decreased the marketable yield. Irrigation production efficiency of tomato for two lateral spacing is presented in Fig 3. The seasonal water applied for different irritation levels ranged from $98 \mathrm{~mm}$ to $882 \mathrm{~mm}$ whereas the irrigation production efficiency for $\mathrm{LS}_{1}(0.5)$ and $\mathrm{LS}_{2}(1.0) \mathrm{m}$ lateral spacing $14.22 \mathrm{~kg} / \mathrm{m}^{3}$ and $12.74 \mathrm{~kg} / \mathrm{m}^{3}$ respectively.

Irrigation production efficiency and lateral spacing relationship as $0.5 \mathrm{~m}$ lateral spacing was more as compare to $1.0 \mathrm{~m}$ lateral spacing. The overall results presented in Table1 clearly reveled that irrigation at $175 \%$ of an evaporation replenishment resulted in higher yield $(57.66 \mathrm{t} / \mathrm{ha})$ but irrigation production efficiency was higher at $25 \%$ of pan evaporation replenishments reported the higher marketable yield $\left(28.81 \mathrm{~kg} / \mathrm{m}^{3}\right)$ and irrigation production efficiency at $175 \%$ of pan evaporation replenishment under agro climatic condition of northwestern.

Table.2. Effect of irrigation schedules and lateral spacing on marketable yield and irrigation production efficiency to tomato.

\begin{tabular}{|c|c|c|}
\hline Treatment & $\begin{array}{l}\text { Mean marketable Yield } \\
(\mathrm{t} / \mathrm{ha})\end{array}$ & $\begin{array}{c}\text { Mean irrigation } \\
\text { production efficiency }\left(\mathrm{kg} / \mathrm{m}^{3}\right)\end{array}$ \\
\hline \multicolumn{3}{|c|}{ Pan evaporation Replenishment (\%) } \\
\hline 25 & 28.19 & 28.81 \\
\hline 75 & 44.77 & 15.19 \\
\hline 125 & 47.60 & 9.70 \\
\hline 175 & 57.66 & 8.38 \\
\hline 225 & 53.61 & 6.07 \\
\hline LSD (0.05) & 1.52 & 0.80 \\
\hline \multicolumn{3}{|c|}{ Lateral spacing } \\
\hline $0.5 \mathrm{~m}$ & 49.23 & 14.22 \\
\hline $1.0 \mathrm{~m}$ & 43.50 & 12.74 \\
\hline LSD (0.05) & 0.96 & 0.50 \\
\hline \multicolumn{3}{|c|}{ Interaction } \\
\hline LSD (0.05) & 2.15 & 1.13 \\
\hline
\end{tabular}

The seasonal water applied and marketable yield to tomato for $0.5 \mathrm{~m}$ ( $\mathrm{R}$ $=0.9546)$ and $1.0 \mathrm{~m} \quad\left(\mathrm{R}^{2}=0.9436\right)$ lateral spacing exhibited a strong quadratic relationship. The marketable yield of tomato increased with an increase in seasonal water applied up to $685 \mathrm{~mm}$ and 732 for 0.5 and $1.0 \mathrm{~m}$ lateral spacing respectively and there after yield tended to decline (Fig. 2).
The relationship between pan evaporation replenishment and marketable yield of tomato for two lateral spacing are presented in Fig.3. The pan evaporation replenishment for different irrigation levels ranged from $25 \%$ to $225 \%$ whereas the marketable yield for $0.5 \mathrm{~m}$ and 1.0 lateral spacing ranged from $30.27 \mathrm{t} / \mathrm{ha}$ to $61.05 \mathrm{t} / \mathrm{ha}$ and $26.12 \mathrm{t} / \mathrm{ha}$ to $54.27 \mathrm{t} / \mathrm{ha}$ respectively. The 
pan evaporation replenishment and marketable yield to tomato for $0.5 \mathrm{~m}\left(\mathrm{R}^{2}=0.9546\right)$ and 1.0 $\mathrm{m}\left(\mathrm{R}^{2}=0.9436\right)$ lateral spacing exhibited a strong quadratic relationship. The marketable yield of tomato increased with an increase in pan evaporation replenishment up to $166 \%$ and $212 \%$ for $0.5 \mathrm{~m}$ and $1.0 \mathrm{~m}$ lateral spacing respectively and there after yield tended to decline.

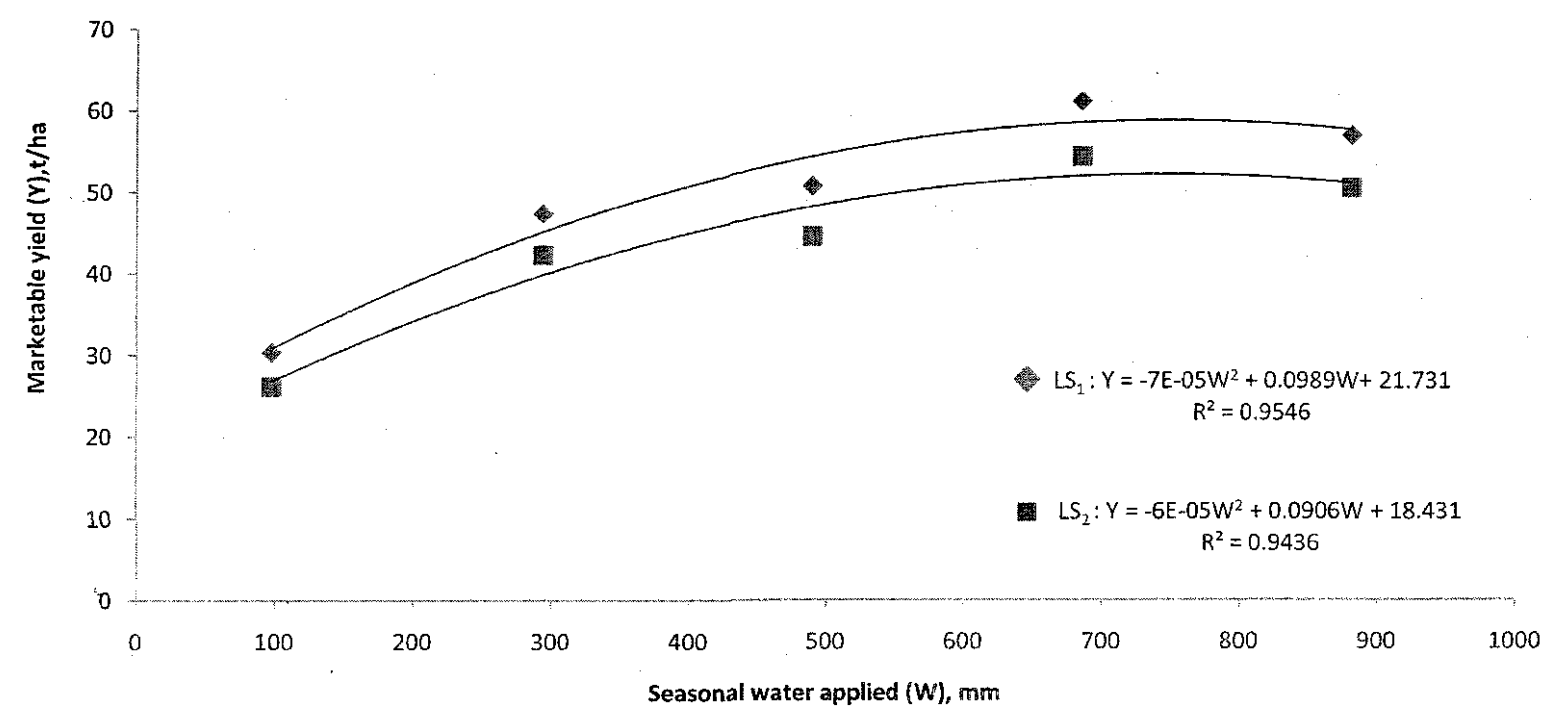

Fig.2: Relationship between seasonal water applied and marketability yield of tomato

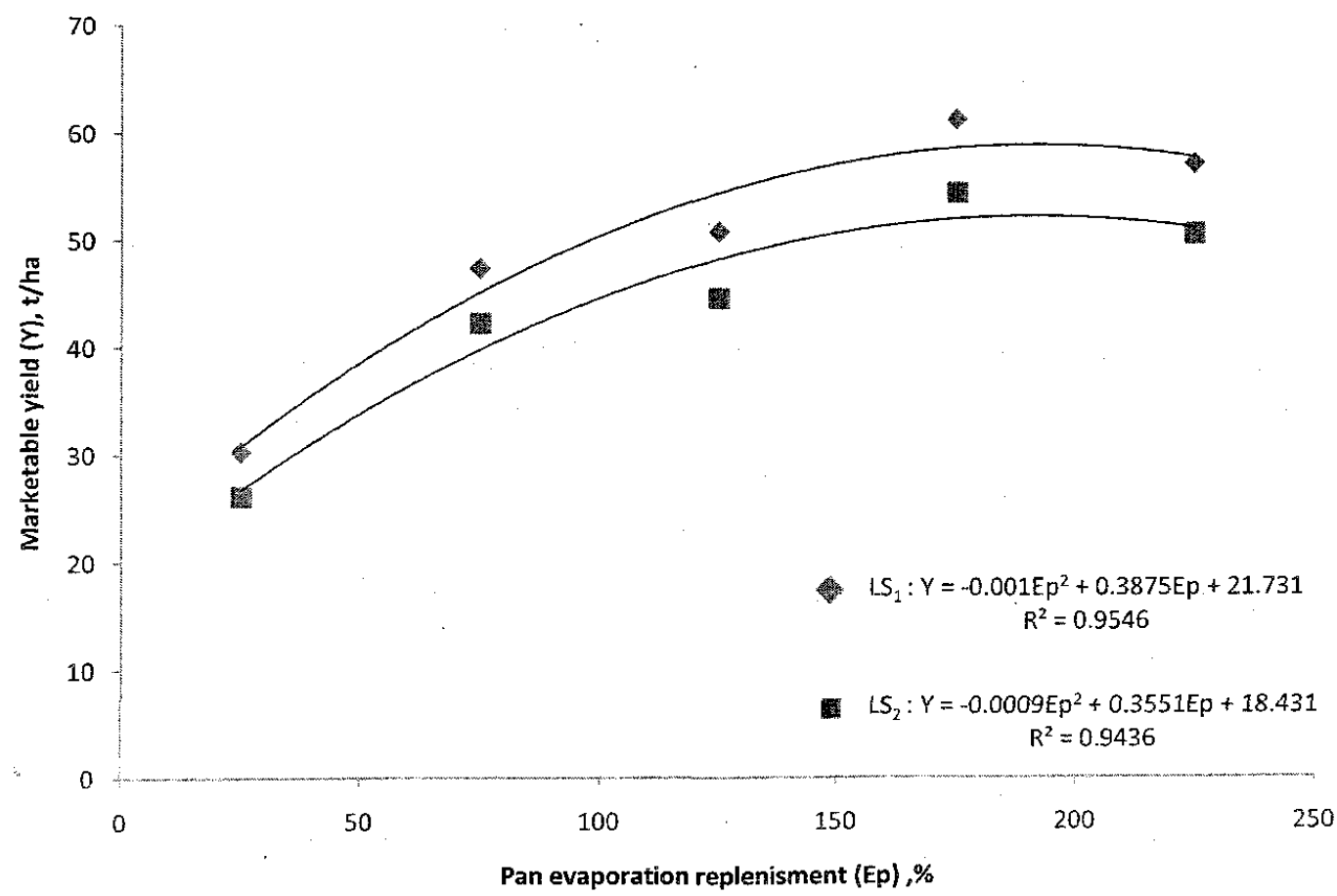

Fig.3: Relationship pan evaporation replenishment and market ability yield of tomato 
The relationship between seasonal water applied and gross return of tomato for two lateral spacing are presented in Fig.2. The seasonal water applied for different irrigation levels ranged from $98 \mathrm{~mm}$ to $882 \mathrm{~mm}$ whereas the gross return for $0.5 \mathrm{~m}$ and $1.0 \mathrm{~m}$ lateral spacing ranged for Rs.151350/ha to Rs.3305250/ha and Rs.130600/ha to Rs.271350/ha respectively. The seasonal water Conclusion

Irrigation at $0.5 \mathrm{~m}$ lateral spacing and $175 \%$ of pan evaporation in replenishment resulted in significantly higher marketable yield of tomato, whereas irrigation production efficiency was higher with irrigation at $25 \%$ of pan evaporation replenishment. A further increase in irrigation level resulting from $225 \%$ of pan evaporation replenishment reduces both marketable yield and irrigation production efficiency. The lateral spacing of $0.5 \mathrm{~m}$ gave higher marketable yield and irrigation production efficiency as compared with $1.0 \mathrm{~m}$ lateral spacing.

\section{References}

1. Ayers, J.E., Phene, C.J., Schoneman, R.A., Meso, B., Dale, F. and Penland J. (1995). Impact of bed location on the operation of subsurface drip irrigation systems. In: Proc. 5th int. Microirrigation Congress, ASAE, p.168-174.

2. Bresler, E. (1977): Trickle-drip irrigation: Principles and applications to soil-water management. Advances in Agronomy, 29: 343-393.

3. Breslur, E. (1978). Analysis of trickle irrigation with application to sedign problem. Irrigation Science, 1:3-17.

4. Bucks, D.A., Nakayama, F.S. and Warrick, A.W. (1982). Principles, Practices and potentialities of trickle (drip) irrigation. In: Hillel, D. (eds), Advances in irrigation Vol.1. Academic Press Inc., New York, pp. 219-298.

5. Doss, B.D., Turner, J.L. and Evans, C.E.(1980). Irrigation methods and inrow chiseling for tomato production. applied and gross return of tomato for $0.5 \mathrm{~m}$ $\left(\mathrm{R}^{2}=0.9546\right)$ and $1.0 \mathrm{~m}\left(\mathrm{R}^{2}=0.9489\right)$ lateral spacing exhibited a strong quadratic relationship (Fig. 3). Gross return of tomato increased with an increase in seasonal water applied up to $685 \mathrm{~mm}$ and $732 \mathrm{~mm}$ for $0.5 \mathrm{~mm}$ for 0.5 and $1.0 \mathrm{~m}$ lateral spacing respectively and there after it tended to decline.

Journal of American Society for Horticulture Science, 105 (4): 611-614. Farah, S.M., Salih, A.A., Taha, A.M., Ali, Z.I. and Ali, I.A. (1997). Grain sorghum response to supplementary irrigations under post-rainy season conditions. Agricultural Water Management, 33: 31-41.

6. Grimes, D.W., Schweers, V.H. and Wiley, P.L. (1976). Drip and furrow irrigation of fresh market tomatoes on a slowly permeable soil. California Agriculture, 30: 8-13.

7. Hanson, E.G., Williams, B.C., Fangmeier, D.D. and Wilke, O.C. (1970). Influence of subsurface irrigation on crop yield and water use. In Proc. National Irrigation Symposium, pp. D1- D13. St. Joseph. Mich.: ASAE.

8. Imtiyaz, M., Mgadla, N. P., Manase, S. K., Chendo, K. and Mothobi, E. O. (2000). Yield and economic return of vegetable crops under variable irrigation. Irrigation Science, 19: 87-93

9. Jadhav, S.S., Gutal, G.B. and Chougule, A.A. (1990) Cost economics of the drip irrigation system for tomato crop. In Proceedings of the First International Congress on the Use of Plastics in Agriculture, New Delhi, $26^{\text {th }}$ February $-2^{\text {nd }}$ March, 1990.

10. Parihar (1974). Scheduling of irrigation to wheat using pan evaporation. Indian Journal of Agricultural Science. 44: 567. 571.

11. Sammis, T.W. (1980): Comparison of sprinkler, trickles, subsurface, and 
furrow irrigation methods for row crops. Agronomy Journal, 72: 701-704.

13. Wanjura, D. F., Upchurch, D. R. and Mahan, J.R. (1990). Evaluation Decision Criteria for irrigation Scheduling in Cotton. Transaction of the ASAE, 33 (2): 512-518.
12. Sivanappam, R.K., Kumar, O.P. and Kumar, V. (1987). Drip irrigation. 